\title{
Compressive Strength of Direct Tooth Colored Restorative Materials
}

\author{
S M Abdul Quader ${ }^{1}$, M. Shamsul Alam², A Asgor Moral ${ }^{3}$, M R Howlader ${ }^{4}$, S Sultana Chowdhury ${ }^{5}$ \\ Fahd A.A. Karim ${ }^{6}$
}

\section{AFFILIATION:}

1. Associate Professor,

Dept. of Conservative Dentistry \& Endodontics, Update Dental College \& Hospital, Dhaka

2. Professor \& Chairman,

Dept. of Conservative Dentistry \& Endodontics, Faculty of Dentistry, BSMMU, Dhaka.

3. Professor,

Dept. of Conservative Dentistry \& Endodontics, Faculty of Dentistry, BSMMU, Dhaka.

4. Associate Professor,

Dept. of Conservative Dentistry \& Endodontics, Faculty of Dentistry, BSMMU, Dhaka.

5. Associate Professor,

Dept. of Conservative Dentistry \& Endodontics, Update Dental College \& Hospital, Dhaka

6. Assistant Professor,

Dept. of Conservative Dentistry \& Endodontics, Update Dental College \& Hospital, Dhaka

\section{Article info.}

Received: $20^{\text {th }}$ July, 2018

Accepted: $10^{\text {th }}$ December, 2018

Volume: 9, Issue-2 October, 2019

DOI:

https://doi.org/10.3329/updcj.v9i2.43738

\section{(c) (1)}

(C) Authors retain copyright and grant the journal right of first publication with the work simultaneously licensed under Creative Commons Attribution License CC - BY 4.0 that allows others to share the work with an acknowledgment of the work's authorship and initial publication in this journal.

https://creativecommons.org/licenses/by/4.0/

Publisher: Update Dental College, Dhaka, Bangladesh

Web: www.updatedentalcollege.edu.bd

E-mail: updcj@hotmail.com

\author{
* Corresponding Author \\ Dr. S M Abdul Quader Rubel \\ Associate Professor \\ Department of Conservative Dentistry \& Endodontics \\ Update Dental College \& Hospital, Turag, Dhaka. \\ E mail: smilezonedental@yahoo.com \\ Mobile: +8801911384858 \\ https://orcid.org/0000-0002-0646-6843
}

\section{Citation}

S M Abdul Quader, M. Shamsul Alam, A Asgor Moral, M R Howlader, S Sultana Chowdhury. Compressive Strength of Direct Tooth Colored Restorative Materials Update Dental College Journal. 2019 October; 9(2): 36-39

DOI: https://doi.org/10.3329/updcj.v9i2.43738

\section{ABSTRACT}

New materials are being introduced to address the need for restoring both carious and non carious (caused by a combination of abrasion, erosion and abfraction) lesions. In an era when more and more patients are retaining their natural dentition, the need for this restoration is increasing. The ideal materials should be adhesive, tooth colored and abrasion-resistant Materials and Methods: Seven disc samples of Compomer, Giomer \& Composite restorative materials were prepared for measurement of compressive strength. Results: The value of Compressive strength of Giomer becomes high in comparison to Compomer but not significant in comparison to Composite.

\section{Keywords: Mechanical properties, Giomer, Compressive strength}

Introduction:

During the last decade, resin based composite materials have used widely to restore posterior teeth ${ }^{1}$. Occlusal and proximal wear have been identified as possible limitations of resin based composite materials in posterior restorations. Other areas of concern include marginal leakage, discoloration, polymerization shrinkage and post operative sensitivity ${ }^{2}$. Some of these clinical characteristics have improved over time as the adhesive technology has advanced and additional features, such as fluorides, have been added to the materials ${ }^{3,4,5}$. The mechanical properties, bonding properties and fluoride release abilities vary substantially across the continuum ${ }^{6,7,8,9}$. Since compomers, glass ionomers, and resin modified glass ionomers are weaker than composite resins, the clinical application of fluoride releasing materials is usually limited to non load bearing areas ${ }^{8}$. As we move across the continuum from glass ionomers and resin modified glass ionomers, to compomers and composite resins, the compressive strengths generally increase. One of the reasons is that the resin contents of each class of materials increase in the same trend. The cross linked polymer matrices in compomers and composite ( typically copolymes of Bis-GMA, UDMA and TEGMA) generally have higher strength and toughness than the gel network formed by acid base reaction in glass ionomers.

Filler load and composition may have significant influence on the mechanical properties. For the same type of materials, mechanical properties generally increase with the increase of the filler load. Fluoroaluminosilicate glass in the major component of the filler in all fluoride releasing materials. Calcium is the essential part of glass filer particles in glass ionomers and resin modified glass ionomers. It initiates the reaction with the acids or polyacids to form crosslinked gel network. The Ca-Al-F silicate glass fillers are mote soluble and weaker than those fillers used in composites that does not contain calcium. This partially contributes to the lower mechanical properties of glass ionomers and resin modified 
glass ionomers. In addition, composite resins often contain hard, insoluble silica ( $\mathrm{SiO} 2$ ) particles, which are not present in glass ionomers and resin modified glass ionomers. This also leads to the higher strength of composite resins ${ }^{8}$.

As giomer is a new product having cross linked polymer matrices, the compressive strength and toughness of the materials also seems to be higher than the gel network formed by acid base reaction in glass ionomers. Generally, it is found that the materials having high fluoride release property has low compressive strength. However, from clinical demand a materials that has high fluoride release and recharge ability as well as high compressive strength is considered better restorative materials. As giomer is resin- based PRG fillers, its compressive strength is expected to be comparable to any other resin based material.

\section{Materials \& Methods}

Study design : Experimental study, Place and period of study The study was conducted in the Department of Conservative Dentistry \& Endododntics, Bangabandhu Sheikh Mujib Medical University (BSMMU), Dhaka in collaboration with Department of Analyrical Research Division, Bangladesh Council of Scientific and Industrial Research Laboratories (BCSIR), Dhaka and Department of Pilot Plant \& Process Development Centre, BCSIR Dhaka, between January 2007 to December 2008.

Sample size: Seven disc samples of Comomer, Giomer \& Composite restorative materials were prepared for measurement of compressive strength.

\section{Study procedure}

\section{Materials used:}

The materials used in this study are listed in table-I

Composite (Quixfil, Caulk/ Dentsply, Germany) contained a fluoro alumino silicate glass, which has no glass ionomer hydrogel component, in a resin matrix.

Compomer (Dyract Extra, Dentsply Detrey, Germany) contained a strontium fluorosilicate glass in which a limited glass ionomer hydrogel formation will be possible through a delayed acid base reaction.

Giomer (Beautiful II, Shofu Inc, Japan) in which the fluoridated flass filler will be fully reacted with acid to form an extensive glass ionomer hydrogel layer before blending with a resin.

Table I. Restorative materials used in this study

\begin{tabular}{cllll}
\hline \multicolumn{1}{c}{ Type } & Manufacturer & $\begin{array}{l}\text { Resin liquid } \\
\text { composition }\end{array}$ & Filler composition & $\begin{array}{c}\text { Materials } \\
\text { Trade } \\
\text { name }\end{array}$ \\
\hline Compomer & $\begin{array}{l}\text { Dentsply, } \\
\text { Caulk, } \\
\text { Germany }\end{array}$ & $\begin{array}{l}\text { TCB, } \\
\text { UDMA }\end{array}$ & $\begin{array}{l}\text { Sr-F-silicate glass } \\
\text { SrF2 }\end{array}$ & $\begin{array}{l}\text { Dyract } \\
\text { Extra }\end{array}$ \\
\hline Giomer & Shofu, Japan & Bis-GMA & SPR Fluorobora- & Beautifil \\
& & TEGDMA & $\begin{array}{l}\text { AL-silicate glass } \\
\text { filler, Nano Filler }\end{array}$ & \\
& & & $\begin{array}{l}\text { Multi Fluoroboro- } \\
\text { AL-silicate glass } \\
\text { filler }\end{array}$ & \\
\hline Composite & Dentsply, & Urethane- & Urethane-modified & Quixfil \\
& Caulk, & modified & Bis-GMA & \\
& Germany & Bis-GMA & &
\end{tabular}

For compressive strength measurement, a Teflon mold was constructed $4 \mathrm{~mm}$ in diameter and $6 \mathrm{~mm}$ in depth. The assembled mold was filled with materials, any excessive materials were squeeze out and two microscope glass slides were placed over both ends of the mold. All specimens were light cured through the glass slides for $40 \mathrm{sec}$ top and bottom surfaces. Then the specimens were taken out from the mold and again light curing for $40 \mathrm{sec}$ on each cylindrical side surface. A visible light unit (selector, Taiwan) was used throughout the study. After polymerization all specimens were removed from the molds and then stored for $24 \mathrm{hr}$ at $37^{\circ} \mathrm{C}$ in dry condition. The specimens were ground with a dry 800 grit silicon carbide paper and their diameter and thickness was measured.
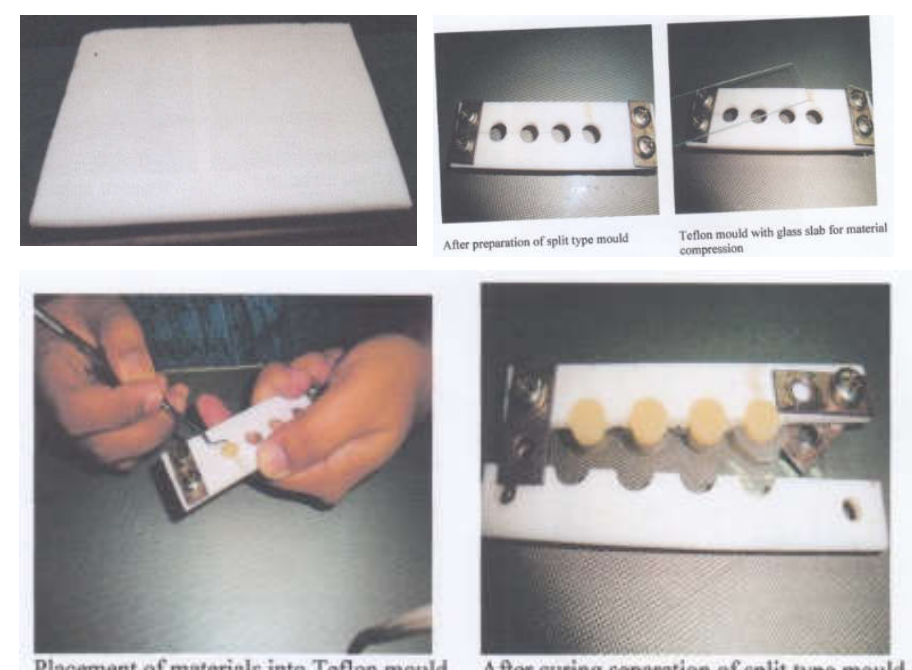

Compressive strength experiment procedure:

After measurement of all the surfaces of the samples, the specimens were placed into a compressive strength tester (Testomertic AX, Universal Testing Machine) and were loaded (Cross-head speed $1.0 \mathrm{~mm} / \mathrm{min}$ ) to the fracture of the sample. The compressive strength for each specimen was determined from Eq.

$$
\mathrm{CS}=\text {---------------- }
$$

Where CS is the compressive strength in $\mathrm{MPa}, \mathrm{P}$ is the load at fracture, and $r$ is the radius of the specimen.

Compressive strength:

Table II. Compressive strength of Giomer, Compomer and Composite

\begin{tabular}{lcccc}
\hline \multicolumn{6}{l}{ Compressive strength (MPA) } & & \\
\hline Material & $\mathrm{n}$ & Range & Mean SD & P value \\
\cline { 1 - 4 } Giomer & 7 & $246.113-305.752$ & $271.356+19.653$ & \multirow{2}{*}{$>0.05^{\mathrm{ns}}$} \\
\cline { 1 - 4 } Compomer & 7 & $151.943-327.488$ & $203.444+59.345$ & \\
\cline { 1 - 4 } Composite & 7 & $146.265-3.2 .234$ & $238.598+57.338$ & \\
\hline
\end{tabular}


ANOVA, ns= Not significant

Table II shows the highest mean compressive strength was found in Giomer and lowest mean compressive strength was found in Compomer.

The mean difference in compressive strength between giomer and compomer, giomer and composite \& compomer and composite was statistically not significant $(\mathrm{P}>0.05)$.

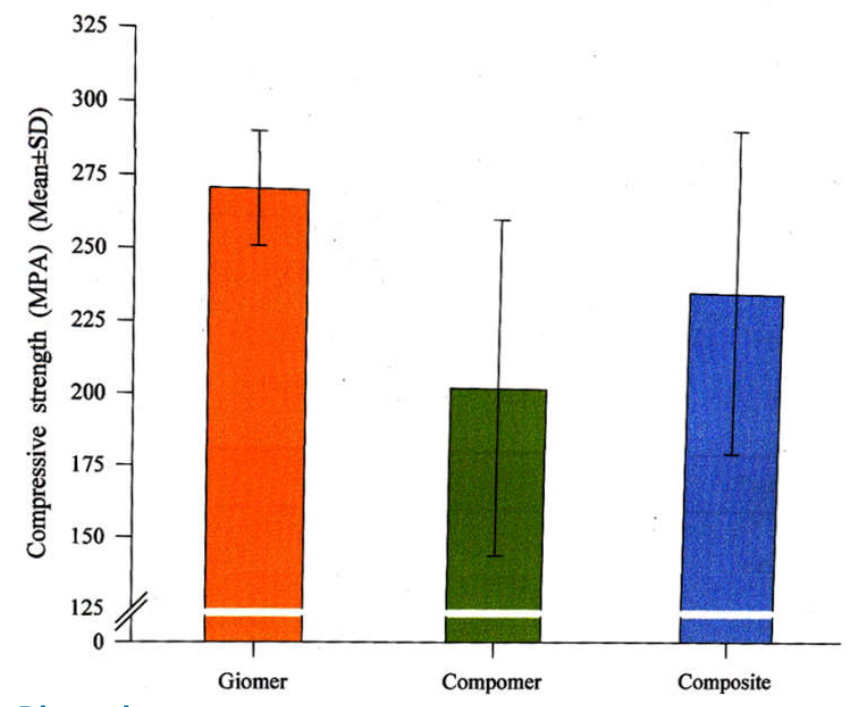

Discussion

The present work has been designed to study giomer, compomer, glass ionomer and composite where seven disk samples were used to examine their compressive strength. The present study has revealed important information regarding compressive strength. The results of this study have been compared with that of different authors and researchers. Observed results of different parameters showed some similarity as well as dissimilarity with the available information present on different publication. In the present study, the mean SD compressive strength of giomer was $271.356+19.653$ $\mathrm{MPa}$. Regarding compressive strength of giomer comparison could not be shown due to lack of data from other study.

$\mathrm{Xu}$ et al. (2003) found the mean compressive strength of compomer $262 \mathrm{MPa}$. This finding is higher than the present study finding. The difference may be due to small sample size, defect in storage of sample of due to manufacturers problem $^{10}$. Xu et al. (2003) found the mean compressive strength of composite $265 \mathrm{MPa}$. This result supports the present result ${ }^{10}$. The value of compressive strength of giomer is greater than that of compomer and composite.

$\mathrm{Xu}$ et al. 2003 indicates the correlation between the compressive strength and fluoride release that-materials with high fluoride release have lower compressive strength. In the present study we can see that compressive strength of giomer is higher than compomer but fluoride release of both of them is similar ${ }^{10}$. Finally, a low release of fluoride from dental materials may have clinical implications in vivo. Fluoride release from glass ionomer restorations increases the fluoride concentration in saliva and in adjacent hard dental tissues. Thus, continuous small amounts of fluoride supporting the teeth decreases demineralization of the tooth tissues although, it is not proven by prospective clinical studies whether the incidence of secondary caries can be significantly reduced by the fluoride release of restorative materials ${ }^{11}$. Cate et al. 1998 deduced that dentin demineralization was inhibited in a clinically relevant percentage only at fluoride levels above $1 \mathrm{ppm}^{12}$. Near optimum fluoride effects can be achieved with quite low concentrations in a daily fluoride rinse ${ }^{13}$. The effect of a very low amount of continuous fluoride release from giomers and compomers on dental hard tissues needed to be further studied.

\section{Conclusions and recommendations}

Current restorative materials with a high fluoride release generally have lower mechanical properties. Therefore, they may not be as durable clinically as lower fluoride release materials, particularly in load bearing areas. Materials that have high fluoride release, high recharge capability, excellent mechanical properties and bonding properties are highly desirable and will be the targets of future development and Giomer to be a better restorative materials other than any fluoride releasing restorative materials.

\section{References:}

1. Abdulla, Al \& Alhadainy, HA 1996, '2-year clinical evaluation of class I posterior composite', Am J dent, vol. 9, no. 4, pp.150-2.

2. Collins, CJ, Bryant, RW \& Hodge, KL 1998, 'A clinical evaluation of posterior composite resin restorations: 8-year findings', J Dent, vol.26,no.4, pp.3117.+ https://doi.org/10.1016/S0300-5712(97)00019-5

3.Major, IA, Moorhead, JE \& Dahl, JE 200, 'Reasons for replacement of restrorations in permanent teeth in general dental practice', Int Dent J, vol.50, no.6, pp. 360-6.

https://doi.org/10.1111/j.1875-595X.2000.tb00569.x PMid:11197194

4. Baratieri, LN \& Ritter, AV 2001, 'Four-year clinical evularion of posterior resin based composite restorations placed using the total etch technique', J Esthet Restor Dent, vol.13, no 1, pp.50-7.

https://doi.org/10.1111/j.1708-8240.2001.tb00251.x PMid:11831309

5. Turkun, LS \& Aktener,BO 2001, 'Twenty four month clinical evaluation of different posterior composite resin matrials', JADA vol.132, no.2, pp. 196203.https://doi.org/10.14219/jada.archive.2001.0155

PMid:11217593

6. Gladys, S, Van Meerbeeck, B, Braem, M, Lambrechts, P \& Vanherle, G 1997, 'Comparative physico-mechanical characterization of new hybrid restorative materials with conventional glass ionomer and resin composite restorative materials', J Dent Res, vol.76, pp.833-95.

https://doi.org/10.1177/00220345970760041001 PMid:9126185

7. Burgess, JO \& Xu, x 1998, 'fluoride releaseing materials', Dent Advisor, vol.15, no.10, pp.1-5.

8. Xu, X \& Burgess. JO 1998, 'fluoride release and compressive strength of fluoride releasing materials', J Dent Res, vol.77, pp.242 (AADR Abstract \# 1091).

9. Albers, HF 19998, "Fluoride containing restoratives" ADEOT Reg, vol.5, pp.41-52.

10. Xu, X \& Burgess. JO 2003, 'Compressive strength fluoride release and recharge of fluoride releasing materials', Biomaterials, vol.24, pp.2451-61. https://doi.org/10.1016/S0142-9612(02)00638-5 
11.Wiegand, A Buchala, W \& Attin, T 2007, 'Review on fluoride releasing restorative materials, fluoride release and uptake characterisistics, antibacterial activity and influence on caries formation', dental materials, vol.23, no.3, pp.343-362.

https://doi.org/10.1016/j.dental.2006.01.022 PMid:16616773

12. Cate, JM, Damen, JJ \& Buijs, MJ 1998, 'Inhibition of dentin demineralization by fluoride in vitro', Caries Res, vol.32, no.2, pp.141-147.

https://doi.org/10.1159/000016444 PMid:9544863

13. Featherstone, JD, Glena, R, Shariati, M, \& Shields, CP1990, 'Dependence of in vitro demineralization of apatite and remineralization of dental enamel on

fluoride concentration', J. Dent. Res vol.69, pp.634-36.

https://doi.org/10.1177/00220345900690S121 PMid:2312892 